\title{
ANALISIS KOMUNIKASI PEMASARAN DALAM MENARIK PENGUNJUNG (STUDI PADA KAMPOENG KOPI BANARAN, PT. PERKEBUNAN NUSANTARA IX KABUPATEN SEMARANG)
}

\author{
Marketing Communication Analysis For Attracting Visitors \\ (A Study at Kampoeng Kopi Banaran, PT. Perkebunan Nusantara IX \\ Semarang Regency)
}

\author{
Eunike Sipayung ${ }^{1 *}$ Sony Heru Priyanto ${ }^{2 *}$ \\ Program Studi Agribisnis \\ Fakultas Pertanian dan Bisnis \\ Universitas Kristen Satya Wacana \\ *E-mail : eunikesipayung97@gmail.com dan sonecid@yahoo.com
}

\begin{abstract}
This research was conducted in Kampoeng Kopi Banaran (Kakoba), an agrotourism owned by PT. Perkebunan Nusantara IX (Persero) located in the area of coffee plantation Getas Afdeling Assinan, Jl. Raya Semarang - Solo KM 1,5. Thisresearch aims to: (1) knowing Kakoba's marketing communication (2) knowing the changing and factors affecting Kakoba's marketing communications(3) knowing the impact of Kakoba's marketing communication changes in attracting visitors. This research was conducted on February - March 2018. The participants of this research were the management of Kakoba. Data collection techniques used were observation, interviews, and study documentation.This study used a qualitative approach with descriptive design.The research results explain Kakoba marketing communication strategies are: advertising, direct marketing, and sales promotion. There is one discovery about marketing communication strategy: private relation. There are other types of communication: physical environment and quality of services that support the delivery of messages to visitors. Factors affecting the changing of marketing communications in Kampoeng Kopi Banaran is technology and information, as well as the better assessment and consumer knowledge. The impact of agrotourism marketing communication changes in Kakoba is the increasing number of visitors from year to year.

Keywords: agrotourism, marketing communication, visitors.
\end{abstract}

\section{ABSTRAK}

Penelitian ini dilakukan di Kampoeng Kopi Banaran (Kakoba), sebuah agrowisata yang dimiliki oleh PT. Perkebunan Nusantara IX (Persero) yang berlokasi di perkebunan kopi Getas Afdeling Assinan, Jl. Raya Semarang - Solo KM 1,5. Penelitian ini bertujuan untuk: (1) mengetahui komunikasi pemasaran Kakoba (2) mengetahui perubahan dan faktor-faktor yang mempengaruhi komunikasi pemasaran Kakoba (3) mengetahui dampak perubahan komunikasi pemasaran Kakoba dalam menarik pengunjung. Penelitian ini dilakukan pada bulan Februari - Maret 2018. Partisipan dalam penelitian ini adalah manajemen Kakoba. Teknik pengumpulan data yang digunakan adalah observasi, wawancara, dan studi dokumentasi. Penelitian ini menggunakan pendekatan kualitatif dengan desain deskriptif. Hasil penelitian menjelaskan strategi komunikasi pemasaran Kakoba adalah: periklanan, pemasaran langsung, dan promosi penjualan. Ada satu penemuan tentang strategi komunikasi pemasaran: hubungan pribadi. Ada jenis komunikasi lain: lingkungan fisik dan kualitas layanan yang mendukung pengiriman pesan kepada pengunjung. Faktor yang mempengaruhi perubahan komunikasi pemasaran di Kampoeng Kopi Banaran adalah teknologi dan informasi, serta penilaian dan pengetahuan konsumen yang lebih baik. Dampak dari perubahan komunikasi pemasaran agrowisata di Kakoba adalah meningkatnya jumlah pengunjung dari tahun ke tahun. 
JURNAL ILMIAH AGRINECA

ISSN : 2721-074X (Online) - 2301-6698 (Print)

Available on : http://ejournal.utp.ac.id/index.php/AFP/index

This is Under CC BY SA Licence

Kata kunci: agrowisata, komunikasi pemasaran, pengunjung.

\section{PENDAHULUAN}

Sebagai makhluk hidup, tentu manusia tidak pernah lepas dari perubahan. Demikian juga dengan pemasaran yang berubah dari waktu ke waktu seiring dengan perkembangan zaman. Salah satu perubahan dalam pemasaran adalah mengenai komunikasi. Akibat perubahan terhadap komunikasi tersebut pula perusahaan memiliki kemampuan baru, yaitu mempercepat komunikasi antara pelanggan secara online maupun offline. Perusahaan harus peka dan merespon perkembangan tersebut secara signifikan.

Indonesia mempunyai potensi besar untuk menjadi kawasan tujuan wisata dunia, khususnya Kabupaten Semarang yang memiliki potensi pariwisata yang cukup menarik minat pengunjung, baik wisatawan domestik maupun mancanegara. Kampoeng Kopi Banaran merupakan salah satu agrowisata yang dimiliki oleh PT. Perkebunan Nusantara IX (Persero), yang terletak di Areal Perkebunan Kopi Kebun Getas Afdeling Assinan tepatnya di Jl. Raya Semarang - Solo KM. 1,5 dengan ketinggian 480 - 600 mdpl dengan suhu udara antara $23^{\circ} \mathrm{C}-27^{\circ} \mathrm{C}$. Pada awalnya PT. Perkebunan Nusantara IX hanya menjual kopi dalam bentuk biji kopi (green beans). Kemudian, pada tahun 2002 perusahaan membuat suatu terobosan dengan cara memperkenalkan produk hilir dalam bentuk kopi bubuk yang kemudian berkembang menjadi "Kampoeng Kopi Banaran". Apabila dibandingkan dengan wisata lain yang berada di Kabupaten Semarang, Kampoeng Kopi Banaran merupakan agrowisata lengkap (One Stop Tourism and Education Service), karena memiliki keunikan tersendiri yaitu fokus pada tanaman kopi dan menawarkan 20 jenis wahana wisata dan 11 jenis paket wisata murid sekolah. Kawasan agrowisata ini terus dikembangkan dengan memberikan berbagai macam tambahan fasilitas penunjang.
Wisata yang meyakinkan harus bisa memberikan pelayanan, pengetahuan serta kepuasan bagi para konsumen. Oleh karena itu, dibutuhkan komunikasi pemasaran yang tepat untuk mengembangkannya.Tujuan komunikasi pemasaran adalah memengaruhi atau memberikan efek langsung kepada perilaku khalayak sasaran (Shimp, 2003).Menurut penelitian terdahulu oleh Rachman (2014), kesuksesan suatu perusahaan tergantung pada cara perusahaan mengelola hubungan baik dengan masyarakat. Untuk memanfaatkan peluang yang ada, perusahaan haruslah menggunakan metode komunikasi pemasaran modern dengan tujuan agar informasi tentang produk atau jasa yang ditawarkan dapat diakses oleh target konsumen secara cepat dan tepat melalui berbagai saluran komunikasi, baik secara langsung maupun tidak langsung. Menurut penelitian Lailatul et al., (2014) menyimpulkan bahwa strategi komunikasi pemasaran Kusuma Agrowisata yang target pokoknya yaitu pelajar dengan menggunakan 
JURNAL ILMIAH AGRINECA

ISSN : 2721-074X (Online) - 2301-6698 (Print)

Available on : http://ejournal.utp.ac.id/index.php/AFP/index

This is Under CC BY SA Licence

jasa direct sales. Hambatan Strategi Komunikasi Pemasaran Kusuma Agrowisata Batu adalah bahwa kurang maksimalnya buah yang dihasilkan oleh kebun di tempat wisata ini, serta kurangnya fasilitas hiburan yang sangat mempengaruhi kebetahan serta kepuasan dari pengunjung. Sedangkan penelitian Naik \& Peters (2009)menyimpulkan bahwa terdapat sinergi antara media offline dan online dan dapat dihitung menggunakan data pasar.

Tabel 1. Jumlah Kunjungan Wisatawan Kakoba Tahun 2012 - 2016

\begin{tabular}{cc}
\hline Tahun & Jumlah \\
\hline 2012 & 82.843 \\
2013 & 82.127 \\
2014 & 90.816 \\
2015 & 113.728 \\
2016 & 118.926 \\
Rerata & 97.688
\end{tabular}

Sumber: Badan Pusat Statistik Kabupaten Semarang

Berdasarkan Tabel 1. dari tahun ke tahun jumlah pengunjung Kampoeng Kopi Banaran semakin meningkat kecuali pada tahun 2013 karena tahun 2013 merupakan tahun transisi atau peralihan bagi manajemen Kakoba, dimana pada tahun-tahun sebelumnya Kakoba masih mengikuti manajemen kebun dan belum sebagai unit tersendiri. Kakoba menjadi unit tersendiri pada tahun 2014 dan pada tahun inilah Kakoba dapat mengelola unitnya secara keseluruhan mulai dari fasilitas hingga pencatatan jumlah pengunjung. Strategi komunikasi pemasaran yang dilakukan oleh manajemen Kampoeng Kopi Banaran salah satunya dengan melalui website dan media sosial berupa Facebook dan Instagram telah dianggap efektif.

Dalam peneltian ini penulis akan mencoba mendeskripsikan upaya-upaya yang dilakukan oleh Kampoeng Kopi Banaran mengenai komunikasi pemasaran dalam menarik pengunjung agrowisata (Hariyadi, Huda, Ali, \& Wandik, 2019). Perkembangan komunikasi, faktor-faktor yang memengaruhi beserta dampak perubahan komunikasi pemasaran akan turut diteliti.

\section{METODE PENELITIAN}

Penelitian ini dilakukan di Kampoeng Kopi Banaran yang merupakan salah satu agrowisata yang dimiliki oleh PT. Perkebunan Nusantara IX (Persero), yang terletak di Areal Perkebunan Kopi Kebun Getas Afdeling Assinan tepatnya Jl. Raya Semarang - Solo KM 1,5. Pemilihan tempat didasarkanbahwa Kampoeng Kopi Banaran sendiri merupakan agrowisata lengkap (One Stop Tourism and Education Service). Penelitian dilakukan pada bulan Februari hingga Maret 2018.Berdasarkan pendekatannya, penelitian ini merupakan penelitian deskriptif kualitatif. Adapun subjek penelitian adalah pihak manajemen Kampoeng Kopi Banaran. Objek penelitian dalam tulisan ini meliputi: komunikasi pemasaran, perkembangan, faktor yang memengaruhi dan dampak perubahan komunikasi pemasaran agrowisata di Kampoeng Kopi Banaran dalam menarik pengunjung. Data yang digunakan adalah data primer dan data sekunder. Teknik pengumpulan data yang digunakan ada;ah observasi, wawancara, dan studi dokumentasi.

Dalam penelitian ini terdapat dua partisipan yaitu Asisten Manager Promosi \& IT, serta Karyawan Marketing Kakoba. Penentuan partisipan menggunakan teknik purposive. Dalam hal ini peneliti memilih partisipan yang dianggap mengetahui informasi dan masalah secara mendalam, serta dapat dipercaya. Uji keabsahan data yang digunakan dalam penelitian ini yaitu triangulasi.

\section{HASIL DAN PEMBAHASAN}

\section{Target Pasar}

Berdasarkan hasil penelitian, diketahui bahwa Kakoba tidak menargetkan pasarnya secara spesifik pada usia tertentu dan produk wisata yang terdapat di Kakoba dapat dinikmati oleh semua kalangan, namun ketika ditanyai mengenai target pasar yang ingin dituju, maka Kakoba akan menargetkan organisasi utama pembelian yaitu keluarga yang terdiri dari Ayah, Ibu dan anak. Menurut Kotler dan Keller (2009), keluarga merupakan organisasi pembelian konsumen yang paling penting dalam masyarakat, dan anggota keluarga mempresentasikan kelompok referensi utama yang paling berpengaruh. Semua 
JURNAL ILMIAH AGRINECA

ISSN : 2721-074X (Online) - 2301-6698 (Print)

Available on : http://ejournal.utp.ac.id/index.php/AFP/index

This is Under CC BY SA Licence

kebutuhan rekreasi keluarga tersedia di Kakoba mulai dari resort dan hotel, restoran, mart, wahana wisata, dan lainnya. Kakoba menyediakan semua kebutuhan keluarga berupa restoran untuk Orang Tua, dan aneka wahana yang ramah anak.

Selain keluarga, konsumen yang seringkali berkunjung ke Kakoba adalah murid sekolah yaitu dari Kelompok Bermain (KB), Taman Kanakkanak (TK), dan Sekolah Dasar (SD). Menurut Mayasari dan Ramdhan (2013), perubahan mindset dan gaya hidup masyarakat memicu perkembangan agrowisata, sehingga semakin banyak keluarga dan sekolah-sekolah yang mengadakan kegiatan agrowisata untuk memperkenalkan ilmu pertanian. Biasanya pengunjung murid sekolah melalui guru dan pendamping akan mengambil paket Funtastic yang terdiri dari pilihan wahana flying fox kids, outbound kids, kereta wisata, berenang, wisata edukasi dan kunjungan pabrik kopi.

Kakoba mempertimbangkan ukuran pasar yaitu banyaknya jumlah konsumen yang mungkin menjadi pengunjung. Dalam penelitian ini diketahui bahwa semua kalangan sebagai target atau sasaran pasar Kakoba, namun secara lebih spesifik target pasarnya yaitu kalangan keluarga dan murid sekolah. Penentuan target pasar ini mempermudah Kakoba dalam merancang pesan dan memilih saluran komunikasi pemasaran yang efektif (Lupioyadi, 2012).

\section{Kemasan Pemasaran}

Kemasan tidak hanya penting dalam komunikasi pemasaran produk barang, tetapi juga penting dalam produk jasa, khususnya agrowisata. Kemasan pemasaran yang dimaksud dalam penelitian ini adalah bagaimana cara pemasar menyajikan produk wisata. Kemasan Kakoba berupa produk dan paket wisata, view atau pemandangan Kakoba, dan lokasi Kakoba yang strategis.

Jika kemasan yang berupa produk dan paket wisata yang ditawarkan menarik, maka pengunjung akan tertarik untuk datang. Kakoba memiliki 20 jenis wahana wisata dan 11 jenis paket wisata untuk memenuhi keinginan pengunjung. Menurut Purnama (2009), variasi paket wisata yang beragam ini memungkinkan pengunjung untuk memilih apa yang menarik bagi dirinya sehingga memberikan kepuasan terhadap kebutuhan akan hiburan. Selain paket wisata tersebut, Kakoba juga menyediakan berbagai fasilitas penunjang seperti convention hall, meeting room, camping ground, dan lainnya.

Kemasan lain Kakoba yang menarik pengunjung adalah adanya view atau pemandangan Rawa Pening dan Gunung Telomoyo yang menghadirkan suasana alami dan hawa sejuk memberikan kenyamanan kepada para pengunjung. Lokasi Kakoba yang strategis dan akses yang mudah dijangkau, hanya $200 \mathrm{~m}$ dari pintu keluar tol Semarang - Bawen memungkinkan pengunjung untuk datang. Kakoba terletak di simpang tiga akses kota-kota besar: Semarang, Jogja, dan Solo. Ketika melakukan perjalanan, pengunjung akan melewati Kakoba dan memutuskan untuk singgah atau transit, atau sekedar beristirahat sambil mencoba berbagai wahana wisata.

Kakoba menarik pengunjung tanpa harus melalui interaksi secara langsung namun juga dapat melalui media atau channel komunikasi pemasaran berupa brosur, video, dan foto. Kakoba tidak perlu repot-repot menjelaskan secara panjang lebar ataupun harus selalu ada setiap saat untuk menjelaskan produknya, tetapi hanya dengan melihat kemasan saja, orang akan tertarik untuk berkunjung.

\section{Channel Komunikasi Pemasaran}

Channel atau saluran komunikasi pemasaran yang dimaksud dalam penelitian ini adalah media yang digunakan pemasar untuk memasarkan produk wisatanya dan bagaimana mengkomunikasikan produk-produk tersebut, mengenai apa yang sedang dilakukan, dan apa yang dijual. Channel komunikasi pemasaran tersebut terwujud dalam berbagai macam bentuk bauran promosi yang bertujuan untuk mengenalkan kepada masyarakat tentang keberadaan produk wisata yang dimiliki. Channelkomunikasi pemasaran ini juga menjadi titik tumpu dalam kegiatan komunikasi pemasaran dan kunci keberhasilan penjualan produk wisata Kakoba.

Melalui channel komunikasi pemasaran Kakoba ingin memberitahu masyarakat tentang apa saja yang ada di Kakoba. Pada tahun 2014, 
JURNAL ILMIAH AGRINECA

ISSN : 2721-074X (Online) - 2301-6698 (Print)

Available on : http://ejournal.utp.ac.id/index.php/AFP/index

This is Under CC BY SA Licence

Kakoba melakukan pembenahan pada channel komunikasi pemasaran yang telah uzur atau kadaluwarsa, seperti nomor telepon yang sudah tidak aktif dan harga lama yang telah berubah. Kakoba mulai dari perbaikan nomor telepon yang terdapat pada brosur dan price list, e-mail, dan website. Perbaikan tersebut mungkin terlihat sederhana namun membawa dampak yang sangat penting. Dengan perbaikan nomor telepon, alamat e-mail, dan website yang benar dapat membuat konsumen lebih mudah menghubungi pihak Kakoba.

Perkembangan dan perubahan komunikasi pemasaran membawa dampak positif terhadap jumlah pengunjung yang datang ke Kakoba karena perkembangan ini memungkinkan Kakoba dan konsumen untuk saling berkomunikasi dengan akses cepat dengan jangkauan yang semakin luas, dan tidak dibatasi dimensi ruang dan waktu. Konsumen semakin tahu dan mengerti tentang produk apa saja yang di Kakoba dan didukung oleh data berupa foto, video, dan lainnya. Memperbaiki channelkomunikasi pemasaran berarti memperbaiki cara konsumen dalam mengetahui tentang Kakoba. Semakin banyak orang yang tahu tentang Kakoba dengan baik, maka semakin banyak pula konsumen yang akan berkunjung.

Kakoba menggunakan tidak hanya satu jenis namun berbagai jenis media atau channel dalam memasarkan produk wisatanya serta tidak semua channel komunikasi pemasaran sama efektifnya. Kakoba harus benar-benar profesional dalam memilih channel komunikasi pemasaran yang terbaik dan yang sesuai dengan produknya.

Kakoba memaksimalkan peluang yang dimiliki dengan menggunakan semua channel komunikasi pemasaran yang memungkinkan. Bentuk strategi yang dilakukan oleh Kakoba dalam mengkomunikasikan produknya yaitu dengan melakukan kegiatan melalui periklanan (advertising), pemasaran langsung (direct marketing), promosi penjualan (sales promotion), selaras dengan teori Shimp (2003) dan temuan strategi komunikasi lainnya yaitu private relation.Berikut adalah channel komunikasi pemasaran berupa bauran promosi yang dilakukan oleh Kampoeng Kopi Banaran dalam menarik pengunjung:

\section{Periklanan (Advertising)}

Periklanan pada Kakoba merupakan kegiatan atau aktivitas untuk mempromosikan produk wisata baik melalui media cetak maupun media elektronik. Cara periklanan yang paling konvensional atau paling biasa digunakan Kakoba adalah brosur, price list, dan gambar-gambar promosi. Konsumen dapat mengetahui jenis wahana wisata, fasilitas apa saja yang tersedia beserta harga yang sudah tertera secara rinci. Hal ini dilakukan karena sebelum melakukan kunjungan atau perjalanan, calon pengunjung biasanya akan berorientasi atau merujuk pada brosur, foto-foto, atau video yang menggambarkan tempat tujuan (Foster, 2000) dan diharapkan dapat menumbuhkan kepercayaan konsumen dan keputusan pembelian pada produk agrowisata.

Diketahui bahwa karena tuntutan perkembangan teknologi dan informasi membuat Kakoba melakukan media periklanan yang baru yang lebih murah, dan berpotensi lebih efektif daripada media yang telah ada. Pendapat tersebut muncul disebabkan iklan online lebih unggul daripada media tradisional, karena iklan online memberikan kendali yang hampir penuh kepada konsumen atas informasi iklan yang kemudian akan dipilih untuk diterima atau dihindari (Shimp, 2014). Pemasar juga dapat membangun hubungan dengan para konsumen melalui komunikasi dua arah. Media internet yang saat ini banyak digunakan adalah media sosial.

Media sosial seperti Facebook dan Instagram memiliki berbagai jenis kelebihan dibanding dengan mengiklankan secara tradisional, yaitu lebih praktis untuk dilihat dan ditonton, serta hampir semua orang menggunakan media sosial dari gadget masing-masing. Denganberiklan melalui media sosial, Kakoba dapat menjadi 'wadah' untuk para konsumennya. Kakoba akan lebih mudah untuk melakukan promosi atau untuk sekedar berinteraksi dengan konsumen. Dilihat dari sudut pandang perusahaan, penggunaan sosial media dapat menekan pengeluaran perusahaan. Biasanya konsumen akan meninggalkan komentar pada postingan Kakoba, atau Kakoba akan merepost postingan konsumen yang sudah berkunjung. Sesuai dengan teori Kotler \& Keller (2009), pemasar 
JURNAL ILMIAH AGRINECA

ISSN : 2721-074X (Online) - 2301-6698 (Print)

Available on : http://ejournal.utp.ac.id/index.php/AFP/index

This is Under CC BY SA Licence

menggunakan internet sebagai saluran informasi dan penjualan yang kuat, dengan jangkauan geografis yang lebih luas dalam memberi informasi kepada konsumen dan mempromosikan produknya di seluruh dunia.

Dalam penelitian ini, Kakoba belum pernah mengiklankan produknya di media elektronik televisi dikarenakan biaya untuk iklan yang sangat besar. Oleh karena itu Kakoba terbuka kepada siapa saja yang ingin mengadakan liputan mengenai kawasan agrowisata.Beberapa stasiun televisi yang meliput biasanya berupa program berita maupun edukasi seperti Reportase dari Trans TV, NET 12 dari NET TV, Metro TV, Tribun Jateng dan Panorama Jawa Tengah dari ANTV. Hal ini tentu menguntungkan karena dalam program-program tersebut produk Kakoba akan diulas secara ringkas dan menarik sehingga konsumen tertarik untuk berkunjung ke Kakoba.

Selain menggunakan media televisi, Kakoba juga menggunakan Online Travel Agent (OTA). Pada dasarnya OTA memiliki lingkup bisnis selayaknya travel agent konvensional. Hanya saja layanan OTA berbasis digital, dimana transaksi layanan informasi, jual beli, dan pembayaran terjadi secara online. Salah satu OTA yang digunakan adalah Traveloka untuk Banaran 9 Resort dan Hotel. Sebelumnya Kakoba juga menggunakan OTA Agoda namun ternyata tidak efektif sehingga dihentikan penggunaannya. Traveloka yang sekarang menjadi salah satu primadona dalam dunia bisnis StartUP Indonesia memudahkan setiap orang ketika ingin berlibur khususnya yang memiliki jadwal kerja yang padat ingin mencari tempat liburan menarik ketika akhir pekan atau hari libur tiba. Semua informasi yang dibutuhkan sudah tertera di laman Traveloka seperti harga, fasilitas, tempat menarik terdekat, hingga review (ulasan) pengunjung.

Sebelum menggunakan internet, Kakoba sering beriklan melalui surat kabar khususnya Suara Merdeka, namun seiring dengan perkembangan zaman, hal tersebut dikurangi frekuensinya dan dialihkan kepada periklanan yang lebih mudah dan efektif seperti melalui media sosial.

\section{Pemasaran Langsung (Direct Marketing)}

Pemasaran langsung adalah metode penjualan dimana perusahaan langsung mendekati atau berkomunikasi secara langsung dengan konsumen atau calon pengunjung mengenai produk atau jasa yang ingin ditawarkan dengan adanya respon atau dialog dari kedua belah pihak. Pemasaran langsung yang paling sering dilakukan Kakoba adalah melalui telepon, e-mail, SMS, website, serta WA (WhatsApp Messenger). Brosur dan price list yang semula berformat hardfile kemudian ditambahkan menjadi softfile yang dapat diunggah ke website Kakoba dan dapat dikirimkan melalui WA dan e-mail. Kakoba akan mengirimkan brosur dan price list serta penawaran kepada konsumen mengenai kebutuhan atau paket apa saja yang diinginkan mulai dari konsumsi, fasilitas, dan wahana wisata sehingga mereka dapat mengetahui apa saja yang ada di Kakoba dengan informasi yang lebih lengkap.

Selain melakukan pemasaran langsung seperti di atas, Kakoba juga melakukan jenis pemasaran langsung berupa table top. Table top adalah event atau forum bisnis berbentuk pasar wisata yang dirancang dan diadakan oleh ASPPI (Asosiasi Pelaku Pariwisata Indonesia) dan ASITA (Association of The Indonesian Tours and Travel Agencies) untuk mempertemukan pelaku industri pariwisata dalam hal ini Kakoba menjadi seller dengan pelaku industri pariwisata regional dan internasional dalam hal ini biro tour atau travel agent menjadi buyer secara langsung. Dalam forum ini Kakoba akan menawarkan produk wisata kepada pihak biro untuk mencapai kesepakatan (dealing) mengenai waktu kunjungan dan harga paket wisata. Mengikuti kegiatan table top menjadi salah satu langkah 'menjemput bola' untuk mendongkrak jumlah pengunjung yang akan datang ke Kakoba. Terdapat beberapa jenis table top yang diikuti oleh Kakoba, yaitu Bursa Wisata Indonesia, Borobudur Travel Mart Expo (BTMX), dan Bengawan Solo Travel Mart. Buyer atau biro tour berasal dari dalam dan luar negeri. Buyer yang berasal dari luar negeri biasanya berasal dari negara India, China, dan negara Asia Pasifik lainnya.

Sebelum melakukan table top, pihak penyelenggara akan melakukan open buyer sehingga seller dapat melihat buyer potensial dan kegiatan yang diikuti akan worth it atau setimpal 
JURNAL ILMIAH AGRINECA

ISSN : 2721-074X (Online) - 2301-6698 (Print)

Available on : http://ejournal.utp.ac.id/index.php/AFP/index

This is Under CC BY SA Licence

dengan biaya yang dikeluarkan dimana terciptanya suatu kesempatan dimana seller dan buyer dapat saling berbincang dengan suasana yang kondusif dan berujung pada kesepakatan bisnis.

Sebelum mencapai kesepakatan, konsumen akan melakukan negosiasi dengan Kakoba mengenai harga dan paket wisata. Komunikasi berperan penting dalam proses negosiasi, salah satunya dalam proses menawarkan produk wisata, marketing Kakoba akan mengajukan sejumlah pertanyaan untuk memastikan kebutuhan konsumen. Tidak memotong pembicaraan, selalu menjaga sikap ramah, serta menjadi pendengar yang baik berperan besar dalam mencapai kesepakatan. Hal ini senada dengan pendapat Fisher et al. (2000) dalam Hamdan et al. (2015) yang menyatakan bahwa "proses berkomunikasi, saling mendengarkan pendapat untuk mencapai sebuah persetujuan komunikasi." Dalam negosiasi meski terjadi antara dua pihak dengan latar belakang yang sama, memerlukan upaya sungguh-sungguh untuk mencapai kesepakatan yang menguntungkan bagi kedua belah pihak.

\section{Promosi Penjualan (Sales Promotion)}

Saat pertama kali dibuka, Agrowisata Kakoba hanya mengandalkan komunikasi pemasaran tradisonal yaitu word of mouthatau biasa disebut dengan promosi dari mulut ke mulut yang dilakukan oleh karyawan kepada keluarga, kenalan, dan tetangga mereka. Word of mouth memberikan input yang cukup berharga bagi Kakoba karena word of mouth a dalah opini yang paling jujur dan apa adanya. Promosi yang keluar dari mulut pelanggan yang puas atas Kakoba dapat secara signifikan mendongkrak reputasi Kakoba. Dalam pelaksanaannya, promosi secara word of mouth tidak memerlukan biaya sama sekali. Promosi ini berpengaruh kepada jumlah pengunjung yang datang.

Selain melakukan promosi word of mouth, Kakoba juga mengikuti event pameran. Pameran yang sering diikuti Kakoba adalah pameran atau event tahunan yang diadakan oleh PRPP (Pusat Rekreasi \& Promosi Pembangunan). Pihak Kakoba akan mengambil karyawan yang berasal dari Kantor Direksi Semarang untuk menjadi SPG (Sales Promotion Girl) yang bertugas untuk menarik konsumen untuk berkunjung ke stand dan menawarkan produk kopi dan produk wisatanya.

Pemilihan SPG untuk menarik konsumen adalah salah satu komunikasi nonverbal dengan sense visual, bahwa SPG menyampaikan makna pesan dengan ekspresi wajah positif yang ceria dan bersemangat, kontak mata yang meyakinkan dan memberikan kesan serius, gerakan tangan agar konsumen mudah memahami maksud SPG tersebut, serta penampilan yang terlihat cantik dan menyenangkan untuk dipandang. SPGlebih sering menggunakan bahasa nonverbalnya untuk menguatkan dan melengkapi bahasa verbal.Selaras dengan teori Burgoon dalam Khotimah (2013) yang menyatakan bahwa komunikasi nonverbal yang dilakukan SPGdalam menyapa dan memberikan informasi konsumennya, dapat memberikan kesan bahwa mereka sedang dilayani dengan orang yang ramah.

Promosi penjualan lain yang juga sering dilakukan adalah dengan memberikan diskon atau potongan harga serta bonus kepada pengunjung. Kebutuhan pengunjung dan frekuensi kunjungan menjadi pertimbangan Kakoba dalam memberikan diskon. Menurut penjelasan partisipan 1, pemberian diskon dapat berupa gratis naik kereta wisata, gratis souvenir, atau potongan harga. Kelebihan memberikan diskon adalah untuk meningkatkan penjualan, menarik pelanggan baru, serta mempertahankan pelanggan lama.

Selain mengikuti pameran dan memberikan diskon, Kakoba melakukan promosi penjualan secara online yaitu melalui Youtube dan Google My Business (Google Bisnisku). Google Bisnisku adalah salah satu platform yang disediakan oleh Google, dimana platform ini memberikan manfaat berupa penampilan dalam pencarian di perangkat apapun seperti desktop dan smartphone. Google Bisnisku juga akan menampilkan Google Maps terkait lokasi Kakoba. Dengan adanya verifikasi langsung dari Google, akan timbul kepercayaan konsumen terhadap Kakoba. Google dipilih karena posisinya sebagai mesin pencari yang terkemuka dan menguasai lebih dari $50 \%$ dari semua pencarian internet (Shimp, 2014). Youtube channel Kakoba memuat video-video terkait liputan televisi, dan company 
JURNAL ILMIAH AGRINECA

ISSN : 2721-074X (Online) - 2301-6698 (Print)

Available on : http://ejournal.utp.ac.id/index.php/AFP/index

This is Under CC BY SA Licence

profile. Keuntungan dari membuat Youtube channel adalah memberikan biro tour kemudahan dalam mempresentasikan dan memvisualisasikan Kakoba kepada klien atau calon pengunjung. Konsumen yang ingin berkunjung juga dapat melihat video-video Youtube tersebut sebagai referensi sebelum berkunjung.

Berdasarkan pernyataan di atas, diketahui pula bahwa sebelum berkunjung ke sebuah tempat wisata, konsumen biasanya memiliki referensi yang berguna untuk memberikan gambaran sepintas tentang tempat tersebut. Hal ini selaras dengan teori mengenai faktor lain yang memengaruhi perkembangan komunikasi pemasaran menurut Richard J. Semenik dalam Hermawan (2012), yaitu semakin baiknya penilaian dan pengetahuan konsumen akan informasi produk yang akan dibeli. Konsumen akan mengecek terlebih dahulu produk yang akan mereka beli dengan melihat melalui media sosial.

\section{Private Relation}

Private relation pada Kakoba merupakan kegiatan dimana Kakoba tidak hanya berhubungan dengan pengunjung, tetapi juga harus berhubungan dengan lembaga yang lebih besar yang bersifat pribadi atau eksklusif, seperti dengan mengikuti komunitas atau asosiasi. Asosiasi yang diikuti merupakan suatu perkumpulan yang mewadahi pengusaha atau pelaku usaha di bidang jasa perjalanan wisata di Indonesia. Asosiasi dan komunitas yang diikuti oleh Kakoba adalah PHRI (Perhimpunan Hotel dan Restoran Indonesia), AWAI (Asosiasi Wisata Agro Indonesia), Balangga (Komunitas pariwisata Kabupaten Semarang) dan Salut (Perkumpulan sales dan marketing di area Keresidenan Ambarawa Salatiga Ungaran).

Mengikuti asosiasi atau komunitas wisata sangat penting dalam memajukan pariwisata di Indonesia karena melalui asosiasi kemampuan dan keterampilan para anggota dapat dikembangkan dan ditingkatkan melalui pemberian sertifikasi profesional, serta dapat menjadi wadah dalam mengumpulkan dan menyebarluas-kan informasi mengenai kebijakan pemerintah dan ketentuan lain di bidang usaha perjalanan wisata. Melalui asosiasi juga Kakoba dapat menjual produk wisatanya lewat event atau kegiatan yang diadakan oleh asosiasi tersebut.

Selain mengikuti asosiasi, Kakoba juga melakukan kerjasama dengan biro tour atau agen travel yang terjalin secara tidak resmi atau tanpa adanya MoU (Memorandum of Understanding), karena dengan menggunakan $\mathrm{MoU}$ berarti mewajibkan biro tour untuk membawa kliennya berkunjung ke Kakoba, namun masing-masing klien tentu memiliki keinginan dan jalur perjalanan wisata yang berbeda. Kakoba selalu memelihara hubungan baik dengan biro tour sehingga mereka selalu merekomendasikan Kakoba kepada kliennya sebagai pilihan tempat wisata yang ingin dituju.

Kakoba sangat terbuka terhadap berbagai jenis kerjasama dengan pihak manapun selama kerjasama tersebut memberikan manfaat kepada kedua belah pihak. Dinas dan perusahaan tidak luput dari perhatian Kakoba. Dinas Pendidikan, Dinas Pariwisata, dan Dinas lain sering membawa tamu atau mengadakan rapat. Selain Dinas, Kakoba juga melakukan kerjasama dengan perusahaan-perusahaan. Perusahaan-perusahaan tersebut sering mengadakan event dan outbound. Dengan kerjasama ini, Kakoba memperluas jaringan pemasaran produk wisatanya.

Dalam proses strategi komunikasi melalui private relation, Kakoba memiliki kerjasama dan membina hubungan baik dengan asosiasi, biro tour, perusahaan, maupun instansi pemerintah. Komunikasi merupakan syarat mutlak terjalinnya kerjasama. Terjalinnya komunikasi dengan frekuensi yang lebih sering dan terjadinya proses tukar informasi atau umpan balik, maka hubungan kerjasama yang terjadi antara kedua belah pihak semakin baik. Hubungan ini sangat dibutuhkan bagi kelangsungan Kakoba dalam kerjasama jangka panjang.

\section{Kendala Komunikasi Pemasaran}

Komunikasi pemasaran di Kampoeng Kopi Banaran tak lepas dari segala kekurangannya, Kendala yang dialami Kakoba dalam melakukan komunikasi pemasaran adalah padatnya event yang dilakukan di Kakoba khususnya pada saat peak season (musim puncak) liburan yaitu weekend (Sabtu dan Minggu) dan libur panjang yang mengakibatkan adanya kesalahpahaman atau 


\section{AGRINECA}

JURNAL ILMIAH AGRINECA

ISSN : 2721-074X (Online) - 2301-6698 (Print)

Available on : http://ejournal.utp.ac.id/index.php/AFP/index

This is Under CC BY SA Licence

mis mengenai perubahan kebutuhan dengan pengunjung. Misalnya ketika pengunjung merubah kebutuhan atau adanya penambahan item yang kemudian disampaikan kepada karyawan Kakoba, namun karena padatnya event, karyawan menjadi kurang peka dan kurang tanggap. Kendala ini dapat dicegah dan diminimalisir dengan cara melakukan pengecekan beberapa hari sebelum pelaksanakan kegiatan oleh PIC (Person in Charge) atau karyawan yang bertangung jawab menangani kebutuhan dan perubahan yang akan terjadi.

Kendala lain dalam komunikasi pemasaran Kakoba adalah dalam hal mengelola klien atau pengunjung lama. Kakoba kesulitan mengelola klien lama karena padatnya kegiatan atau acara oleh klien lain dan dibutuhkannya tenaga ekstra untuk mencari data dan menghubungi kembali klien lama tersebut. Kakoba berupaya semaksimal mungkin dalam melayani dan memberikan kepuasan kepada pengunjung yang datang. Jika pelanggan mendapatkan pelayanan yang memuaskan maka dipastikan pengunjung akan datang kembali.

\section{Kelengkapan Kakoba}

Setelah dilakukannya komunikasi pemasaran seperti yang telah dijelaskan di atas, terdapat pula faktor pendukung lain yang menunjang kenyamanan pengunjung yaitu kelengkapan Kakoba berupa produk makanan dan minuman yang ditawarkan melalui Banaran Resto dan Coffee House, serta adanya public goods seperti jogging dan BMX track, tempat parkir yang luas, toilet yang bersih, dan mushola.

Komunikasi pemasaran yang dilakukan Kakoba merupakan strategi standar yang juga dilakukan oleh para pelaku usaha agrowisata lainnya. Namun terdapat satu kekuatan dan keunikan Kakoba yang membuat para pengunjung betah dan selalu berdatangan. Kekuatan tersebut terletak pada komunikasi nonverbal berupa lingkungan fisik. Hightower (2009) dalam Apriliani (2018) membagi dimensi dari lingkungan fisik (servicescape) menjadi tiga dimensi utama yaitu dimensi suasana (ambient dimension), dimensi desain (design dimension), dan dimensi sosial (social dimension).
Dimensi suasana Kakoba berupa keindahan lingkungan Agrowisata Kakoba membuat pengunjung dapat menikmati suasana alami dan jalan khas perkebunan kopi sebagai nilai jual utama dengan udara segar dari pepohonan, serta pencahayaan dari paparan sinar matahari langsung memberikan sensasi berwisata yang tak terlupakan.Selain itu, terdapat pula potensi alam yang berada di sekitar Kakoba. Potensi alam tersebut adalah pemandangan Rawa Pening, Gunung Merbabu, dan Gunung Telomoyo. Potensi alam ini juga dapat dinikmati melalui berbagai spot foto yang telah disediakan oleh Kakoba bagi yang ingin berfoto atau sekedar menunggu antrian kereta wisata. Spot foto ini terbilang unik dan dapat menarik pengunjung karena biasanya mereka berlomba-lomba untuk datang dan mencoba tempat baru tersebut.

Kakoba selalu berusaha untuk mengikuti keinginan konsumen melalui tren yang sedang hangat di masyarakat. Tren spot foto unik ini bermula pada tahun 2017 dimana pengunjung beramai-ramai mengabadikan momen spesial mereka untuk kemudian diunggah ke media sosial. Hal ini terjadi karena orang saat ini lebih senang jika dianggap sebagai orang yang update atau sekarang biasa disebut kekinian (Sutanto, 2017).

Dimensi selanjutnya adalah dimensi desain Kakoba berupa brosur, petunjuk arah yang dapat membantu wisatawan, kondisi fasilitas fisik seperti toilet dan gazebo yang memadai, serta tata letak Kakoba yang strategis dan mudah dijangkau pengunjung.

Desain brosur Kakoba menggunakan tiga warna utama yaitu hijau, oranye, dan kuning. Warna-warna ini tentu memiliki pesan tersendiri yang ingin disampaikan kepada pengunjung. Warna hijau ini diasosiasikan sebagai tumbuhan, lingkungan alam, natural, dan harmoni yang terdapat pada Kakoba. Efek visual yang ditimbulkan berupa kesan ramah dan menyejukkan. Warna oranye menimbulkan kesan kreatif dan energi yang menyehatkan yang dapat dilakukan oleh pengunjung lewat aktivitas wisata yang ditawarkan Kakoba. Warna kuning menimbulkan kesan ceria dan menggembirakan yang dapat diperoleh pengunjung setelah melakukan aktivitas wisata di Kakoba. Perpaduan ketiga warna ini tentunya digunakan untuk 
JURNAL ILMIAH AGRINECA

ISSN : 2721-074X (Online) - 2301-6698 (Print)

Available on : http://ejournal.utp.ac.id/index.php/AFP/index

This is Under CC BY SA Licence

menarik perhatian konsumen untuk berkunjung. Hal ini selaras dengan penelitian Luzar (2011) yang menyatakan bahwa dalam sebuah desain, komposisi warna sangatlah penting yang berarti to compose (mengarang, menyusun, atau mengubah).

Dimensi sosial berupa penampilan karyawan yang menggunakan seragam khusus, keramahan karyawan kepada para pengunjung, serta respon kerjasama Kakoba yang terbuka kepada pengunjung. Pengunjung pada umumnya ingin mendapatkan pengalaman hiburan yang tidak dapat mereka rasakan di tempat wisata lain, oleh karena itu hal-hal fisik yang berada di lingkungan Kakoba memiliki pengaruh sangat penting dalam memberikan kualitas jasa. Jika perkebunan kopi yang terdapat pada Kakoba dihilangkan, maka nilai jual dan keunikan Kakoba yang dapat menjadi penarik minta pengunjung menjadi berkurang.

Bentuk komunikasi pemasaran selain lingkungan fisik adalah kualitas pelayanan jasa yang diberikan kepada pengunjung. Terdapat lima dimensi kualitas jasa menurut Parasuraman et al. (1998) dalam Lupiyoadi (2013) yaitu tangible (berwujud), reliability (kehandalan), responsiveness (ketanggapan), assurance (jaminan), emphaty (empati).

Dimensi tangible berupa karyawan Kakoba menggunakan seragam khusus sehingga pengunjung dapat langsung mengenali karyawan jika membutuhkan sesuatu, kenyamanan dan kemudahan proses dan akses layanan Kakoba kepada pengunjung yang ingin membeli tiket atau memesan tempat. Dimensi reliability berupa kecermatan karyawan dalam melayani pelanggan, standar pelayanan Kakoba yang jelas dan sesuai dengan brosur dan penawaran yang tertera. Dimensi responsiveness berupa kesigapan karyawan terhadap pengunjung yang ingin mendapatkan pelayanan, proses pelayanan Kakoba yang cepat, cermat, dan tepat, serta ketanggapan karyawan terhadap permintaan dan keluhan pengunjung yang segera diproses.

Dimensi assurance Kakoba terdiri dari jaminan tepat waktu dalam pelayanan, jaminan legalitas berupa lembar kesepakatan pihak Kakoba dan pengunjung yang melakukan reservasi dilengkapi dengan materai, serta jaminan kepastian biaya sesuai dengan hasil kesepakatan kedua belah pihak. Dimensi emphaty berupa karyawan Kakoba yang mendahulukan kepentingan pengunjung tanpa membedabedakan, cara melayani dengan sikap ramah, sopan, dan menghargai setiap pengunjung. Kelima dimensi kualitas pelayanan ini menumbuhkan rasa percaya pengunjung kepada Kakoba. Dimensi-dimensi ini tidak dapat dipisahkan dan saling menyokong antara satu dengan yang lainnya sehingga terbentuklah suatu rangkaian komunikasi yang efektif.

\section{KESIMPULAN}

Hasil penelitian ini menunjukkan bahwa bentuk-bentuk komunikasi pemasaran yang saling terkait satu dengan yang lainnya yaitu melalui kegiatan periklanan (advertising), pemasaran langsung (direct marketing), promosi penjualan (sales promotion). Ada temuan satu strategi komunikasi yaitu private relation. Terdapat pula bentuk komunikasi lain yaitu melalui lingkungan fisik dan kualitas jasa yang menjadi penyokong komunikasi pemasaran. Faktor utama yang memengaruhi perubahan komunikasi pemasaran adalah tuntutan perkembangan teknologi dan informasi yang semula dilakukan secara tradisional kemudian berubah menjadi modern dan serba online. Faktor kedua adalah semakin baiknya penilaian dan pengetahuan konsumen akan informasi produk yang akan dibeli. Perkembangan dan paerubahan komunikasi pemasaran membawa dampak positif terhadap jumlah pengunjung dari tahun ke tahun

Kepada pihak Kampoeng Kopi Banaran, perlu dilakukan inovasi baik melalui penambahan armada kereta wisata, penambahan spot top selfie, pemeliharaan public goods seperti toilet, mushola, serta jogging dan BMX track. Kakoba juga perlu memberikan member card kepada pengunjung sehingga Kakoba memiliki database dan dapat lebih mudah menghubungi pelanggan baru dan lama. Kepada pengelola agrowisata lain, sebaiknya lebih memperhatikan lingkungan fisik dan meningkatkan kualitas jasa yang menunjang komunikasi pemasaran dalam menyampaikan pesan kepada pengunjung. Perlu dilakukan penelitian lebih lanjut terkait efektivitas dan 


\section{AGRINECA}

JURNAL ILMIAH AGRINECA

ISSN : 2721-074X (Online) - 2301-6698 (Print)

Available on : http://ejournal.utp.ac.id/index.php/AFP/index

This is Under CC BY SA Licence 